\title{
Medical graduates' early career choices of specialty and their eventual specialty destinations: UK prospective cohort studies
}

\author{
Michael J Goldacre, professor of public health, L Laxton, research officer, T W Lambert, statistician and study \\ coordinator
}

UK Medical Careers Research Group, Unit of Health-Care

Epidemiology, Department of

Public Health, University of Oxford,

Oxford OX3 7LF

Correspondence to: M J Goldacre michael.goldacre@dphpc.ox.ac.uk

Cite this as: $B M J$ 2010;340:C3199 doi:10.1136/bmj.c3199

\section{ABSTRACT}

Objective To report on doctors' early choices of specialty at selected intervals after qualification, and eventual career destinations.

Design Questionnaire surveys.

Setting United Kingdom.

Participants Total of 15759 doctors who qualified in 1974, 1977, 1983, 1993, and 1996, and their career destinations 10 years after graduation.

Results 15759 doctors were surveyed one and three years after graduation and 12108 five years after graduation. Career preferences at years 1, 3, and 5, and destinations at 10 years, were known for, respectively, $64 \%(n=10154), 62 \%(n=9702)$, and $61 \%(n=7429)$ of the survey population. In the 1993 and 1996 cohorts, career destinations matched with year 1 choices for $54 \%$ $(1890 / 3508)$ of doctors in year $1,70 \%(2494 / 3579)$ in year 3 , and $83 \%(2916 / 3524)$ in year 5 . Corresponding results for the earlier cohorts (1974-83) were similar: $53 \%$ (3310/6264), 74\% (4233/5752), and 82\% (2976/3646). The match rates varied by specialty; for example, the rates were consistently high for surgery. Career destinations matched with year 1 choices for $74 \%(722 / 982)$ of doctors who specified a definite (rather than probable or uncertain) specialty choice in their first postgraduate year. About half of those who chose a hospital specialty but did not eventually work in it were working in general practice by year 10 .

Conclusions Ten years after qualification about a quarter of doctors were working in a specialty that was different from the one chosen in their third year after graduation. This stayed reasonably constant across graduation cohorts despite the changes in training programmes over time. Subject to the availability of training posts, postgraduate training should permit those who have made early, definite choices to progress quickly into their chosen specialty, while recognising the need for flexibility for those who choose later.

\section{INTRODUCTION}

The traditional structure of postgraduate medical work and training in the United Kingdom comprised, in sequence, the house officer year (undertaken in the first year after qualification), several senior house officer posts (typically of six months each), entry to specialist training in a registrar post or in general practice, and, for hospital specialists, several further years of training in a senior registrar post before eventually securing a consultant post. In the 1990s a single unified registrar grade was introduced to improve the quality of higher specialist training and shorten its duration. ${ }^{12}$ More recently, the senior house officer grade was reformed with the aim of making it time limited while retaining opportunities for exposure to a variety of specialties and experience before deciding definitively on a specialty.

Further changes came with Modernising Medical Careers: the house officer year and the first senior house officer year were combined into two foundation years, after which it was expected that most doctors would select their career specialty and enter a fixed period of higher medical training. The structure of the Modernising Medical Careers training programme remains under review. ${ }^{4}$ Key issues are when doctors do, and should, decide definitively about their choice of specialty.

Using data from five cohorts of doctors from UK medical schools who graduated between 1974 and 1996, we compared the extent to which choices of specialty at one, three, and five years after graduation corresponded to career destinations 10 years after graduation.

\section{METHODS}

Since 1974 our research group has undertaken postal questionnaire surveys of all doctors who qualified from all UK medical schools in selected whole year cohorts at one, three, and five years after qualification, and at longer intervals thereafter. Our methods are described in detail elsewhere. ${ }^{5}$ For this paper we selected the cohorts of doctors who qualified in 1974, 1977, 1983, 1993, and 1996. These are the cohorts for which we have data about early preferences for career and eventual destinations. The studies are prospective - that is, the early career preferences are those reported by the doctors at the time; for example, the year 1 preferences for doctors who qualified in 1974 are those reported by 
Table 1|Looking forward from early choices: percentage of doctors who practised 10 years after graduation in the mainstream specialty chosen as their untied first choice at one, three, and five years after graduation

\begin{tabular}{|c|c|c|c|c|c|c|c|c|c|c|c|c|c|c|c|c|c|c|}
\hline \multirow[b]{3}{*}{$\begin{array}{l}\text { Untied first } \\
\text { choices }\end{array}$} & \multicolumn{6}{|c|}{ All respondents } & \multicolumn{6}{|c|}{ Men } & \multicolumn{6}{|c|}{ Women } \\
\hline & \multicolumn{3}{|c|}{ 1993, 1996} & \multicolumn{3}{|c|}{$1974,1977,1983$} & \multicolumn{3}{|c|}{ 1993, 1996} & \multicolumn{3}{|c|}{$1974,1977,1983$} & \multicolumn{3}{|c|}{ 1993, 1996} & \multicolumn{3}{|c|}{$1974,1977,1983$} \\
\hline & $\begin{array}{c}\text { Year } \\
1\end{array}$ & $\begin{array}{c}\text { Year } \\
3\end{array}$ & $\begin{array}{l}\text { Year } \\
5\end{array}$ & $\begin{array}{c}\text { Year } \\
1\end{array}$ & $\begin{array}{c}\text { Year } \\
3\end{array}$ & $\begin{array}{c}\text { Year } \\
5^{\star}\end{array}$ & $\begin{array}{c}\text { Year } \\
1\end{array}$ & $\begin{array}{c}\text { Year } \\
3\end{array}$ & $\begin{array}{l}\text { Year } \\
5\end{array}$ & $\begin{array}{c}\text { Year } \\
1\end{array}$ & $\begin{array}{c}\text { Year } \\
3\end{array}$ & $\begin{array}{c}\text { Year } \\
5^{*}\end{array}$ & $\begin{array}{c}\text { Year } \\
1\end{array}$ & $\begin{array}{l}\text { Year } \\
3\end{array}$ & $\begin{array}{l}\text { Year } \\
5\end{array}$ & $\begin{array}{c}\text { Year } \\
1\end{array}$ & $\begin{array}{c}\text { Year } \\
3\end{array}$ & $\begin{array}{c}\text { Year } \\
5^{*}\end{array}$ \\
\hline $\begin{array}{l}\text { Hospital } \\
\text { medical }\end{array}$ & $45.8 \dagger$ & $67.4 \dagger$ & 86.4 & $39.1 †$ & $60.8 \dagger$ & $80.1 †$ & $52.1 \ddagger$ & 70.8 & 89.9 & $43.9 \ddagger$ & 63.2 & 81.8 & $39.4 \ddagger$ & 63.3 & 82.4 & $24.4 \ddagger$ & 51.8 & 71.8 \\
\hline Paediatrics & 54.2 & $62.7 \dagger$ & $76.5 \dagger$ & $35.3 \dagger$ & $59.2 \dagger$ & $74.6 \dagger$ & 55.4 & 63.9 & 73.8 & 38.1 & 65.2 & 79.5 & 53.6 & 62.2 & 77.9 & 32.3 & 51.6 & 67.9 \\
\hline $\begin{array}{l}\text { Accident } \\
\text { and } \\
\text { emergency }\end{array}$ & $26.6 \dagger$ & $52.7 \dagger$ & $76.2 \dagger$ & $10.5 \dagger$ & $31.3 \dagger$ & $56.5 \dagger$ & 36.8 & 58.2 & 80.0 & 16.7 & 35.0 & 63.2 & 17.1 & 47.3 & 71.7 & 0.0 & 25.0 & 25.0 \\
\hline Surgery & 62.1 & 80.7 & 91.6 & 57.5 & 78.0 & 87.0 & 66.0 & 83.4 & 92.4 & $60.0 \ddagger$ & 79.0 & 88.5 & 50.6 & 71.9 & 88.9 & $35.3 \ddagger$ & 69.4 & 70.6 \\
\hline $\begin{array}{l}\text { Obstetrics } \\
\text { and } \\
\text { gynaecology }\end{array}$ & 51.7 & 71.1 & 85.3 & 45.3† & 70.9 & 77.2 & 66.7 & 76.3 & 79.3 & 49.5 & 75.8 & 80.7 & 46.3 & 68.7 & 87.9 & 39.2 & 63.6 & 71.4 \\
\hline $\begin{array}{l}\text { Anaesthet- } \\
\text { ics }\end{array}$ & 60.7 & 81.1 & 93.2 & 68.2 & 80.7 & 85.8 & 65.5 & 83.3 & 95.0 & 71.5 & 81.8 & 88.2 & 56.0 & 78.2 & 90.8 & 62.1 & 78.2 & 79.7 \\
\hline Radiology & $32.1 \dagger$ & 76.3 & 93.2 & $44.7 \dagger$ & 84.9 & 89.5 & 42.9 & 77.8 & 90.3 & 51.0 & 91.4 & 93.0 & 20.0 & 73.9 & 97.6 & 36.1 & 75.5 & 82.4 \\
\hline $\begin{array}{l}\text { Clinical } \\
\text { oncology }\end{array}$ & $25.8 \dagger$ & 66.1 & 84.7 & $32.6 \dagger$ & 69.0 & 84.6 & 18.2 & 59.1 & 79.3 & 37.0 & 67.9 & 83.3 & 30.0 & 70.3 & 87.5 & 26.3 & 71.4 & 86.7 \\
\hline Pathology & 57.1 & 71.0 & 93.3 & 60.7 & 82.2 & 91.9 & 62.5 & 71.8 & 94.4 & 65.0 & 84.7 & 92.6 & 52.0 & 70.4 & 92.5 & 53.5 & 77.8 & 90.7 \\
\hline Psychiatry & $74.8 \dagger$ & $92.5 \dagger$ & $96.6 \dagger$ & $70.8 \dagger$ & $85.4 \dagger$ & 89.0 & 74.0 & 93.3 & 97.7 & 76.2 & 88.7 & 95.9 & 75.8 & 91.7 & 95.6 & 62.5 & 80.6 & 79.7 \\
\hline $\begin{array}{l}\text { General } \\
\text { practice }\end{array}$ & $82.1 \dagger$ & $91.6 †$ & $96.0 \dagger$ & $79.0 \dagger$ & 85.9† & $91.4 \dagger$ & 80.7 & 92.2 & 97.2 & $83.2 \ddagger$ & $89.9 \ddagger$ & $94.8 \mp$ & 82.8 & 91.3 & 95.4 & $72.8 \ddagger$ & $79.8 \ddagger$ & $84.5 \ddagger$ \\
\hline $\begin{array}{l}\text { Public } \\
\text { health }\end{array}$ & 42.9 & 40.0 & 62.5 & $17.0 \dagger$ & $46.0 \dagger$ & $53.7 \dagger$ & 0.0 & - & 0.0 & 26.3 & 61.1 & 63.6 & 60.0 & 40.0 & 83.3 & 11.8 & 40.0 & 48.9 \\
\hline $\begin{array}{l}\text { Other } \\
\text { medical§ }\end{array}$ & $6.3 \dagger$ & $13.2 \dagger$ & $15.3 \dagger$ & $23.2 \dagger$ & 40.9† & $44.4 \dagger$ & 0.0 & 13.6 & 21.7 & 25.0 & 44.8 & 48.8 & 10.3 & 12.9 & 11.1 & 17.4 & 33.3 & 35.0 \\
\hline Total & 59.8 & 77.8 & 89.6 & 61.1 & 78.2 & 86.1 & 62.3 & 79.4 & 90.9 & 64.0 & 80.9 & 89.2 & 57.4 & 76.4 & 88.5 & 55.1 & 72.8 & 78.7 \\
\hline
\end{tabular}

See web extra for numbers on which percentages are based.

* Year 5 data exclude 1983 cohort.

†Significantly higher or lower than average in relevant total column for all respondents ( $\mathrm{P}<0.004$ using adjusted standardised residuals).

†Significantly different for men compared with women ( $P<0.001, \mathrm{x}^{2}$ test with $\mathrm{df}=1$ ).

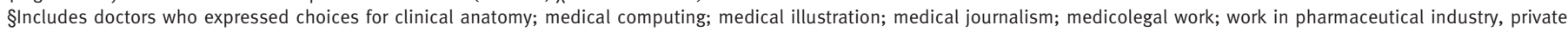

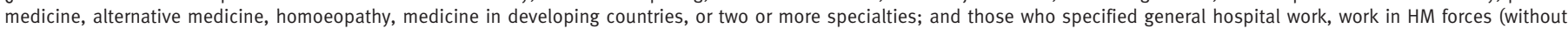
giving details of chosen specialty), and clinical academic work (without further detail).

them back in 1975. Data on early career preferences are linked in subsequent surveys to the individual doctors' replies about changes in choice and eventual career destinations. We used data from eight surveys for doctors who qualified in 1974, seven for those who qualified in 1977, four for those who qualified in 1983, and five each for those who qualified in 1993 and in 1996. We compared preferences for specialties expressed one, three, and five years after graduation with eventual career destinations 10 years after graduation.

We analysed the data for each cohort separately. In the presentation of the results we have combined the doctors who qualified in 1974, 1977, and 1983 and those who qualified in 1993 and 1996 . We did so for two reasons. Firstly, the later generations were more likely than the earlier ones to have worked in training programmes that expected choices to be made reasonably soon after qualification. Secondly, initial analyses showed that for the more recent cohorts the level of agreement between early career choices and eventual destinations for some specialties was generally closer.

We grouped specialties of similar disciplines, such as surgical specialties, into broad "mainstream" groups. Agreement between early choice of specialty and eventual destination, which we refer to as the match rate, was defined as a match within each broad specialty group even when the detail within the group changed. For example, a doctor who specified general surgery as a career preference but eventually practised as an orthopaedic surgeon, counted as a match for the same (broad) specialty as both a choice for and a destination in surgery.

In our survey questions, we asked doctors to specify their choice in their own words and to be as general or specific as they wished. If more than one choice applied, we asked the doctors to list up to three in order of preference and to indicate when choices were of equal preference, which we termed tied choices. Tied choices of different mainstream specialties, such as surgery and general practice, were counted as tied choices. We counted tied choices between specialties within the same mainstream, such as general surgery and orthopaedics, as an untied single choice for the mainstream specialty. For simplicity, the analyses focus principally on untied first choices.

We used $\chi^{2}$ tests to establish statistical significance, in association with adjusted standardised residuals to identify cells in tables that contributed to the overall 


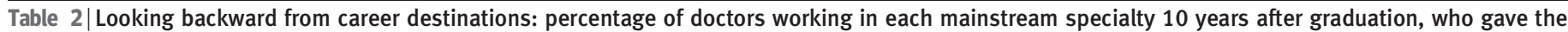
specialty as an untied first choice at one, three, or five years after graduation

\begin{tabular}{|c|c|c|c|c|c|c|c|c|c|c|c|c|c|c|c|c|c|c|}
\hline \multirow[b]{3}{*}{$\begin{array}{l}\text { Untied first } \\
\text { choices }\end{array}$} & \multicolumn{6}{|c|}{ All respondents } & \multicolumn{6}{|c|}{ Men } & \multicolumn{6}{|c|}{ Women } \\
\hline & \multicolumn{3}{|c|}{ 1993, 1996} & \multicolumn{3}{|c|}{$1974,1977,1983$} & \multicolumn{3}{|c|}{ 1993, 1996} & \multicolumn{3}{|c|}{$1974,1977,1983$} & \multicolumn{3}{|c|}{ 1993, 1996} & \multicolumn{3}{|c|}{ 1974, 1977, 1983} \\
\hline & $\begin{array}{c}\text { Year } \\
1\end{array}$ & $\begin{array}{c}\text { Year } \\
3\end{array}$ & $\begin{array}{l}\text { Year } \\
5\end{array}$ & $\begin{array}{c}\text { Year } \\
1\end{array}$ & $\begin{array}{c}\text { Year } \\
3\end{array}$ & $\begin{array}{l}\text { Year } \\
5^{*}\end{array}$ & $\begin{array}{c}\text { Year } \\
1\end{array}$ & $\begin{array}{l}\text { Year } \\
3\end{array}$ & $\begin{array}{c}\text { Year } \\
5\end{array}$ & $\begin{array}{c}\text { Year } \\
1\end{array}$ & $\begin{array}{c}\text { Year } \\
3\end{array}$ & $\begin{array}{c}\text { Year } \\
5^{*}\end{array}$ & $\begin{array}{c}\text { Year } \\
1\end{array}$ & $\begin{array}{c}\text { Year } \\
3\end{array}$ & $\begin{array}{l}\text { Year } \\
5\end{array}$ & $\begin{array}{c}\text { Year } \\
1\end{array}$ & $\begin{array}{c}\text { Year } \\
3\end{array}$ & $\begin{array}{c}\text { Year } \\
5^{*}\end{array}$ \\
\hline $\begin{array}{l}\text { Hospital } \\
\text { medical }\end{array}$ & $63.5 \dagger$ & 70.6 & 84.0 & $58.4 \dagger$ & 70.4 & 83.6 & 67.0 & 74.3 & 87.4 & $62.8 \ddagger$ & 73.5 & $87.9 \ddagger$ & 59.4 & 66.1 & 80.1 & $42.2 \ddagger$ & 59.3 & $66.2 \ddagger$ \\
\hline Paediatrics & $74.1 \dagger$ & $85.1 \dagger$ & 83.8 & $39.0 \dagger$ & $53.5 \dagger$ & $63.1 \dagger$ & 69.5 & 79.3 & 81.8 & 47.7 & $70.8 \ddagger$ & $84.1 \ddagger$ & 76.6 & 87.9 & 84.8 & 31.5 & $38.5 \ddagger$ & $45.0 \ddagger$ \\
\hline $\begin{array}{l}\text { Accident } \\
\text { and } \\
\text { emergency }\end{array}$ & 17.9† & $53.7 \dagger$ & 74.0 & $3.8 \dagger$ & $22.7 \dagger$ & $50.0 \dagger$ & 21.5 & 55.2 & 78.6 & 5.6 & 22.6 & 57.1 & 13.5 & 52.0 & 68.8 & 0.0 & 23.1 & 20.0 \\
\hline Surgery & $90.5 \dagger$ & $89.8 \dagger$ & $94.6 \dagger$ & $81.6 \dagger$ & $93.2 \dagger$ & $97.0 \dagger$ & 92.8 & 89.2 & 94.9 & $84.1 \ddagger$ & 94.4 & 97.4 & 82.5 & 92.1 & 93.6 & $56.6 \ddagger$ & 82.7 & 92.3 \\
\hline $\begin{array}{l}\text { Obstetrics } \\
\text { and } \\
\text { gynaecology }\end{array}$ & $78.4 \dagger$ & $85.1 \dagger$ & 86.2 & 52.2 & 80.7 & 80.7 & 83.9 & 85.3 & 79.3 & 53.0 & 82.4 & 83.6 & 75.8 & 85.1 & 89.2 & 50.9 & 77.8 & 75.8 \\
\hline $\begin{array}{l}\text { Anaesthet- } \\
\text { ics }\end{array}$ & 47.8 & 73.6 & 85.8 & $39.9 \dagger$ & 75.7 & 88.0 & 48.1 & 75.6 & 87.8 & 37.7 & 76.1 & 86.2 & 47.4 & 71.0 & 83.2 & 45.4 & 74.8 & 93.2 \\
\hline Radiology & $16.3 \dagger$ & 44.1† & 89.7 & $22.1 \dagger$ & $63.5 \dagger$ & 83.2 & 20.7 & 50.9 & 93.3 & 22.1 & 61.5 & 85.7 & 10.9 & 36.2 & 85.1 & 22.0 & 67.3 & 77.8 \\
\hline $\begin{array}{l}\text { Clinical } \\
\text { oncology }\end{array}$ & $8.6 \dagger$ & $43.3 \dagger$ & 76.6 & $20.3 \dagger$ & 43.3† & 71.7 & 5.7 & 39.4 & 71.9 & 20.4 & 45.2 & 66.7 & 10.3 & 45.6 & 79.0 & 20.0 & 40.0 & 81.3 \\
\hline Pathology & $25.5 \dagger$ & 58.9 & 79.8 & $43.7 \dagger$ & 72.0 & 76.0 & 33.3 & 60.9 & 82.9 & 45.1 & 73.0 & 79.8 & 20.0 & 57.6 & 77.8 & 41.1 & 70.0 & 70.0 \\
\hline Psychiatry & 52.3 & 71.4 & 81.9 & $42.9 \dagger$ & $67.0 \dagger$ & 79.7 & 55.1 & 74.8 & 82.5 & 51.4 & 74.0 & 87.9 & 49.5 & 68.1 & 81.3 & 32.9 & 58.0 & 69.4 \\
\hline $\begin{array}{l}\text { General } \\
\text { practice }\end{array}$ & $50.0 \dagger$ & 68.5 & 83.2 & $59.6 \dagger$ & $80.8 \dagger$ & $85.7 \dagger$ & 44.3 & $62.3 \ddagger$ & 82.7 & 58.8 & 80.7 & 87.0 & 53.1 & $72.1 \ddagger$ & 83.5 & 61.1 & 80.8 & 82.8 \\
\hline $\begin{array}{l}\text { Public } \\
\text { health }\end{array}$ & $7.5 \dagger$ & $4.5 \dagger$ & $10.4 \dagger$ & $5.1 \dagger$ & $18.6 \dagger$ & $35.0 \dagger$ & 0.0 & 0.0 & 0.0 & 11.1 & 26.8 & 56.0 & 10.3 & 6.5 & 15.2 & 3.1 & 15.7 & 28.2 \\
\hline $\begin{array}{l}\text { Other } \\
\text { medical§ }\end{array}$ & $6.1 \dagger$ & $14.3 \dagger$ & $18.8 \dagger$ & $13.5 \dagger$ & $22.6 \dagger$ & $31.1 \dagger$ & 0.0 & 10.3 & 17.9 & 17.3 & 25.0 & 33.9 & 15.0 & 20.0 & 20.0 & 6.6 & 18.2 & 25.0 \\
\hline Total & 53.9 & 69.7 & 82.7 & 52.8 & 73.6 & 81.6 & 56.7 & 70.5 & 84.6 & 56.1 & 76.8 & 85.9 & 51.3 & 68.9 & 81.1 & 46.6 & 67.3 & 71.9 \\
\hline
\end{tabular}

See web extra for numbers on which percentages are based.

*Year 5 data exclude the 1983 cohort.

†Significantly higher or lower than average in relevant total column for all respondents (P<0.004 using adjusted standardised residuals)

$\ddagger$ Significantly different for men compared with women $(P<0.001, \times 2$ with $\mathrm{df}=1)$.

§See footnote to table 1 .

significance. Transitions between choice and career destination were assessed statistically using tests for symmetry and quasi-symmetry. ${ }^{6}$

\section{RESULTS}

\section{Response rates}

Doctors who qualified in 1974, 1977, 1993, and 1996 were surveyed one, three, and five years after graduation; the cohort of 1983 was surveyed only one and three years after graduation. After exclusion of doctors who died, declined to participate, or were not traceable, response rates to the survey were 84\% (13290/ $15759)$ at one year, $78 \%(12359 / 15759)$ at three years, and $79 \%(9609 / 12108)$ at five years.

Using data from several subsequent surveys, career destinations 10 years after graduation were known for $76 \%(\mathrm{n}=10154)$ of respondents at year 1, 79\% (9702) at year 3 , and $77 \%(n=7429)$ at year 5 ; respective figures for the total survey population were $64 \%(n=10154)$, $62 \%(\mathrm{n}=9702)$, and $61 \%(\mathrm{n}=7429)$.

Looking forward from early choices, analysing career destinations

The results for this analysis are shown for those doctors who gave an untied first choice for each specialty, except where otherwise specified. Table 1 shows the matching between early choice, at years 1,3 , and 5 , and eventual destination. In calculating percentages, the denominators are those who chose each specialty and the numerators are the numbers of these doctors whose destination matched their early choice.

\section{Cohorts of 1993 and 1996}

Early choice of specialty matched eventual career destination for $60 \%(1890 / 3161)$ of doctors in year $1,78 \%$ (2494/3205) in year 3, and 90\% (2916/3253) in year 5 .

The percentage of doctors who eventually practised in their early choice of specialty differed significantly by specialty of early choice $\left(\mathrm{P}<0.001, \chi^{2}\right.$ tests $)$. In each year, the match rate for general practice and psychiatry was significantly higher than the average, and for accident and emergency was significantly lower. In years 1 and 3 the match rate for the hospital medical specialties was significantly lower than the average (table 1).

Match rates for year 1 choices and career destinations at 10 years were $82 \%(634 / 772)$ for general practice and $75 \%(104 / 139)$ for psychiatry (table 1$)$. By year 3 more than $90 \%$ matched for general practice $(92 \%$, $885 / 966)$ and psychiatry $(92 \%, 160 / 173)$, more than $80 \%$ matched for surgery $(81 \%, 388 / 481)$ and anaesthetics $(81 \%, 223 / 275)$, and more than $70 \%$ matched for obstetrics and gynaecology $(71 \%, 86 / 121)$, radio$\operatorname{logy}(76 \%, 45 / 59)$, and pathology $(71 \%, 66 / 93$; table 1$)$. Only 40\% (2/5) matched for public health. By year 5 , 
Table $3 \mid$ Percentage (95\% confidence interval) of doctors working in each mainstream specialty 10 years after graduation, who gave the specialty as an untied first choice one, three, or five years after graduation, according to whether choice was specified as definite, probable, or uncertain

\begin{tabular}{|c|c|c|c|}
\hline \multirow[b]{2}{*}{ Certainty of choice by cohorts } & \multicolumn{3}{|c|}{ Period after graduation } \\
\hline & Year 1 & Year 3 & Year 5* \\
\hline \multicolumn{4}{|l|}{1993 and 1996 graduates: } \\
\hline Definite & 73.5 (70.8 to 76.3$)$ & $86.4(84.7$ to 88.1$)$ & 92.1 (90.8 to 93.1) \\
\hline Probable & $53.6(51.3$ to 56.0$)$ & $69.7(67.4$ to 72.1$)$ & 74.1 (71.4 to 76.8$)$ \\
\hline Uncertain & 28.7 (25.5 to 32.0$)$ & $34.4(29.8$ to 39.0$)$ & $41.3(34.2$ to 48.4$)$ \\
\hline Total† & $53.9(52.2$ to 55.6$)$ & 69.7 (68.2 to 71.2$)$ & $82.7(81.5$ to 84.0$)$ \\
\hline \multicolumn{4}{|l|}{ 1974, 1977, and 1983 graduates: } \\
\hline Definite & $74.2(72.2$ to 76.2$)$ & 86.7 (85.5 to 88.0$)$ & 90.9 (89.7 to 92.1) \\
\hline Probable & 52.2 (50.4 to 53.9$)$ & $68.2(66.2$ to 70.2$)$ & 72.1 (69.3 to 74.8$)$ \\
\hline Uncertain & 23.7 (21.4 to 26.1$)$ & $34.0(30.3$ to 37.7$)$ & $35.0(29.0$ to 41.0$)$ \\
\hline Total† & $52.8(51.6$ to 54.1$)$ & $73.6(72.5$ to 74.7$)$ & 81.6 (80.4 to 82.9$)$ \\
\hline
\end{tabular}

See web extra for numbers on which percentages are based.

Values are calculated from numerator of all doctors in post in year 10 whose specialty in year 10 was that chosen in year 1 (or 3 or 5), and whose choice was definite (or probable or uncertain), and denominator comprising all doctors in cell of table known by us to be in specialty in year 10 and whose year 1 (or 3 or 5 ) intentions and level of certainty of choice were known to us (=100\%)

* Year 5 data excludes the 1983 cohort.

†Includes respondents who did not reply to definiteness of choice question (see web extra).

more than $90 \%$ matched for general practice $(96 \%$, $1068 / 1112)$, psychiatry $(97 \%, 172 / 178)$, surgery $(92 \%, 403 / 440)$, anaesthetics $(93 \%, 260 / 279)$, radio$\log (93 \%, 96 / 103)$, and pathology $(93 \%, 83 / 89)$.

The match rate for women overall was slightly lower than that for men in each year (year $1: \chi^{2}=7.8, \mathrm{df}=1$, $\mathrm{P}=0.01$; year $3: \chi^{2}=4.1, \mathrm{df}=1, \mathrm{P}=0.04$; year $5: \chi^{2}=4.6$, $\mathrm{df}=1, \mathrm{P}=0.03)$. The pattern varied across specialties; the lower match rate for women than for men only attained significance $(\mathrm{P}<0.001)$ for those who chose the hospital medical specialties in year 1 (table 1).

\section{Cohorts of 1974, 1977, and 1983}

Overall, match rates for the doctors who qualified earlier, in 1974, 1977, and 1983 were broadly similar to those for the doctors who qualified in 1993 and 1996, with the exception of year 5 where the later cohorts had a significantly higher match rate than the earlier cohorts $(\mathrm{P}<0.001$; table 1$)$.

As in the later cohorts, match rates between the specialties differed significantly in each year after qualification $(\mathrm{P}<0.001)$. Match rates for general practice were significantly higher than the overall average, and those for the hospital medical specialties, paediatrics, accident and emergency, and public health were lower in each year.

The overall match rate for men and women differed significantly in each year (year $1: \chi^{2}=39.5, \mathrm{df}=1$; year 3 : $\chi^{2}=46.5, \mathrm{df}=1$; year $5: \chi^{2}=66.0, \mathrm{df}=1$; all $\left.\mathrm{P}<0.001\right)$. A consistent contributor to this difference was a substantially lower match rate for women than for men who chose general practice (table 1).

Inclusion of those who gave a tied first choice or no medical choice

A further group of respondents gave tied choices across mainstream specialty groups and a few gave no medical choice: together, these comprised 10\% (347/3508) in year $1,10 \%(374 / 3579)$ in year 3, and 8\% (271/3524) in year 5 . When these doctors were included in the denominators for match rates, an untied first choice matched with eventual career destination for $54 \%$ $(1890 / 3508)$ in year $1,70 \%(2494 / 3579)$ in year 3 , and $83 \%(2916 / 3524)$ in year 5 . The corresponding figures for doctors who qualified in 1974, 1977, and 1983 were $53 \%(3310 / 6264)$ in year $1,74 \%(4233 / 5752)$ in year 3 , and $82 \%(2976 / 3646)$ in year 5 .

Looking back from career destinations, analysing early choices

This set of analyses included all the early choices - tied choices and no expressed choice - of those who were employed in each specialty at year 10. In calculating percentages in this section, the denominators are all doctors who were in the specialty in year 10; and the numerators are all of these doctors who chose the specialty when in years 1,3 , or 5 .

\section{Cohorts of 1993 and 1996}

Eventual career destination matched untied first choices for $54 \%(1890 / 3508)$ of doctors who chose the specialty in year 1, 70\% (2494/3579) who chose it in year 3, and 83\% (2916/3524) who chose it in year 5 (table 2). The percentage of those working in a specialty they had chosen in each of years 1,3 , and 5 differed significantly between the specialties $(\mathrm{P}<0.004)$. The match rate for surgery was consistently higher than the overall average, and that for public health was consistently lower. The match rate with year 1 choice was 91\% (389/430) for surgery, 78\% (76/97) for obstetrics and gynaecology, and 74\% (123/166) for paediatrics (table 2). The match rate with year 3 choice was $90 \%$ (388/432) for surgery, 85\% for paediatrics $(148 / 174)$ and for obstetrics and gynaecology (68/101), and over $70 \%$ for the hospital medical specialties $(71 \%$, $387 / 548)$, anaesthetics (74\%, 223/303), and psychiatry $(71 \%, 160 / 224)$. The match rate with year 5 choices was $95 \%$ (403/426) for surgery and over $80 \%$ for the hospital medical specialties $(84 \%, 450 / 536)$, paediatrics $(84 \%, 140 / 167)$, obstetrics and gynaecology $(86 \%, 81 / 94)$, anaesthetics $(86 \%, 260 / 303)$, radiology $(90 \%, 96 / 107)$, psychiatry $(82 \%, 172 / 210)$, and general practice $(83 \%, 1068 / 1283)$.

The difference in the overall match rate between men and women-women had lower match rates than men-was statistically significant in years 1 and 5 but not in year 3 (year 1: $\chi^{2}=10.1, \mathrm{df}=1, \mathrm{P}=0.001$; year $3: \chi^{2}=0.9, \mathrm{df}=1, \mathrm{P}=0.34 ;$ year $5: \chi^{2}=7.1, \mathrm{df}=1$, $\mathrm{P}=0.01)$.

\section{Cohorts of 1974, 1977, and 1983}

Match rates of those in post in year 10 were similar between the recent and later cohorts (table 2). Career destination matched with early specialty choice for $53 \%$ of doctors' choices in year $1,74 \%$ in year 3 , and $82 \%$ in year 5 . As in the recent cohorts, overall differences $(\mathrm{P}<0.001)$ between the specialties in each of years 1,3 , and 5 were significant. The match rate for 
Table 4 | Untied first choice of career one year after graduation and eventual destination 10 years after graduation for doctors who graduated in 1974, 1977, 1983, 1993, and 1996

\begin{tabular}{|c|c|c|c|c|c|c|c|c|c|c|c|c|c|c|}
\hline \multirow[b]{2}{*}{ Year 1 choice } & \multicolumn{13}{|c|}{ Career destination at year 10} & \multirow[b]{2}{*}{ Total } \\
\hline & $\begin{array}{l}\text { Medical } \\
\text { special- } \\
\text { ties }\end{array}$ & $\begin{array}{l}\text { Paedia- } \\
\text { trics }\end{array}$ & $\begin{array}{l}\text { Accident } \\
\text { and } \\
\text { emer- } \\
\text { gency }\end{array}$ & Surgery & $\begin{array}{l}\text { Obste- } \\
\text { trics and } \\
\text { gynae- } \\
\text { cology }\end{array}$ & $\begin{array}{l}\text { Anaes- } \\
\text { thetics }\end{array}$ & $\begin{array}{l}\text { Radiolo- } \\
\text { gy }\end{array}$ & $\begin{array}{c}\text { Clinical } \\
\text { onco- } \\
\text { logy }\end{array}$ & $\begin{array}{l}\text { Patholo- } \\
\text { gy }\end{array}$ & $\begin{array}{l}\text { Psychia- } \\
\text { try }\end{array}$ & $\begin{array}{l}\text { General } \\
\text { practice }\end{array}$ & $\begin{array}{l}\text { Public } \\
\text { health }\end{array}$ & $\begin{array}{l}\text { Other } \\
\text { medical }\end{array}$ & \\
\hline Medical specialties & 714 & 39 & 19 & 37 & 10 & 79 & 80 & 67 & 87 & 39 & 448 & 26 & 53 & 1698 \\
\hline Paediatrics & 29 & 217 & 7 & 3 & 2 & 10 & 5 & 11 & 21 & 14 & 149 & 17 & 8 & 493 \\
\hline $\begin{array}{l}\text { Accident and } \\
\text { emergency }\end{array}$ & 5 & - & 23 & 7 & 3 & 17 & 1 & 2 & 1 & 1 & 38 & - & - & 98 \\
\hline Surgery & 40 & 9 & 59 & 873 & 14 & 60 & 63 & 6 & 22 & 15 & 277 & 8 & 22 & 1468 \\
\hline $\begin{array}{l}\text { Obstetrics and } \\
\text { gynaecology }\end{array}$ & 10 & 3 & 2 & 6 & 158 & 8 & 3 & 7 & 5 & 6 & 105 & 9 & 6 & 328 \\
\hline Anaesthetics & 24 & 6 & 7 & 3 & 2 & 306 & 8 & 4 & 6 & 4 & 87 & 4 & 13 & 474 \\
\hline Radiology & 20 & 3 & 4 & 2 & 1 & 9 & 55 & 3 & 1 & 2 & 34 & 3 & 1 & 138 \\
\hline Clinical oncology & 20 & 2 & 1 & - & 1 & 1 & 2 & 23 & 4 & 1 & 20 & 1 & 1 & 77 \\
\hline Pathology & 24 & 5 & - & 4 & 1 & 8 & 7 & 3 & 167 & 4 & 40 & 10 & 5 & 278 \\
\hline Psychiatry & 14 & 3 & 2 & 1 & - & 2 & 1 & 2 & 8 & 247 & 45 & 6 & 10 & 341 \\
\hline General practice & 110 & 57 & 19 & 18 & 31 & 76 & 18 & 12 & 27 & 117 & 2379 & 75 & 42 & 2981 \\
\hline Public health & 7 & 6 & - & 2 & 2 & - & - & - & 3 & 4 & 21 & 12 & 3 & 60 \\
\hline Other medical* & 19 & 3 & 6 & 7 & 4 & 7 & 1 & 3 & 13 & 4 & 46 & 8 & 26 & 147 \\
\hline Total & 1036 & 353 & 149 & 963 & 229 & 583 & 244 & 143 & 365 & 458 & 3689 & 179 & 190 & 8581 \\
\hline
\end{tabular}

Emboldened numbers represent matches between career choice and destination.

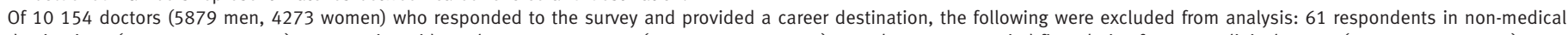

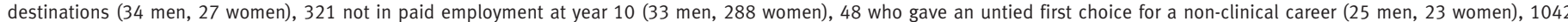
who gave tied first choices (men $\mathrm{n}=569$; women $\mathrm{n}=473$ ), and 101 who gave no career choice at year 1 (71 men; 30 women). 8581 doctors (5147 men, 3434 women) remained.

*See footnote to table 1

surgery and general practice was significantly higher than average in all years. Match rates with year 1 choices were $82 \%(484 / 593)$ for surgery and $60 \%$ $(1745 / 2926)$ for general practice. The match rate was less than $25 \%$ for accident and emergency $(4 \%, 2 / 52)$, radiology $(22 \%, 38 / 172)$, clinical oncology $(20 \%$, $15 / 74)$, and public health $(5 \%, 9 / 176)$. Match rates with year 3 choices were over $80 \%$ for general practice $(81 \%, 2169 / 2686)$, surgery $(93 \%, 497 / 533)$, and obstetrics and gynaecology $(81 \%, 117 / 145)$. Match rates with year 5 choices were $97 \%$ (356/367) for surgery and over $70 \%$ for all specialties except paediatrics (63\%, 94/149), accident and emergency $(50 \%, 13 / 26)$, and public health $(35 \%, 36 / 103)$.

Women had significantly lower match rates than men in each year (year $1: \chi^{2}=50.1, \mathrm{df}=1$; year 3 : $\chi^{2}=59.0 \mathrm{df}=1$; year 5: $\chi^{2}=99.7, \mathrm{df}=1$; all $\mathrm{P}<0.001$ ). Thus the gap between men and women was greater in the earlier than in the later cohorts (table 2).

\section{Certainty of choice}

In each survey, doctors were asked to rate their certainty of choice (definitely, probably, or not really) in response to the question "Have you made up your mind about your choice of specialty?" The level of certainty increased, as expected, from year 1 to year 3 and from year 3 to year 5 . Career choices made by the 1993 and 1996 cohorts combined were regarded as definite by $28 \%(1022 / 3667)$ of responders in year $1,43 \%$ $(1594 / 3741)$ in year 3 , and 63\% $(2330 / 3673)$ in year 5 . The corresponding figures for the 1974,1977 , and 1983 cohorts combined were 29\% (1901/6847), 50\%
(2999/5961), and 63\% (2365/3756). The doctors' early rating of level of choice was highly predictive of whether they practised in their chosen specialty (table 3). Findings were similar for the 1993 and 1996 cohorts and for the 1974, 1977, and 1983 cohorts (table 3).

Transitions between early choice and eventual destination The emboldened numbers on the diagonals in tables 46 show matches between early choice and later destinations. Mismatches between choice and destination (the off-diagonal numbers) decreased substantially from year 1 to year 3 to year 5 .

The off-diagonal elements of the tables are dominated by the transition to general practice from an earlier different choice of specialty: these changes comprised 48\% (1243/2610) of all the doctors who chose a hospital specialty in year 1 and then changed choice, $45 \%(597 / 1319)$ in year 3 , and 44\% (228/519) in year 5 . The percentage of doctors who changed to general practice varied significantly by specialty of initial choice in each year $(\mathrm{P}<0.001)$. Doctors who initially chose paediatrics or obstetrics and gynaecology in year 1 were more likely than others to work eventually in general practice (32\% and 30\%, respectively, changed to general practice). Doctors who were least likely to work eventually in general practice were those who in year 1 chose psychiatry (13\% changed to general practice), pathology (14\% changed), anaesthetics $(18 \%)$, or surgery $(19 \%)$. Doctors who in year 3 aspired to a career in obstetrics and gynaecology or anaesthetics were the most likely to change to general 
Table 5 | Untied first choice of specialty three years after graduation and career destination 10 years after graduation for doctors who graduated in 1974 , $1977,1983,1993$, and 1996

\begin{tabular}{|c|c|c|c|c|c|c|c|c|c|c|c|c|c|c|}
\hline \multirow[b]{2}{*}{ Year 3 choice } & \multicolumn{14}{|c|}{ Career destination at year 10} \\
\hline & $\begin{array}{l}\text { Medical } \\
\text { special- } \\
\text { ties }\end{array}$ & $\begin{array}{l}\text { Paedia- } \\
\text { trics }\end{array}$ & $\begin{array}{l}\text { Accident } \\
\text { and } \\
\text { emergen- } \\
\text { cy }\end{array}$ & Surgery & $\begin{array}{l}\text { Obste- } \\
\text { trics and } \\
\text { gynaecol- } \\
\text { ogy }\end{array}$ & $\begin{array}{l}\text { Anaes- } \\
\text { thetics }\end{array}$ & $\begin{array}{l}\text { Radiolo- } \\
\text { gy }\end{array}$ & $\begin{array}{l}\text { Clinical } \\
\text { oncology }\end{array}$ & $\begin{array}{l}\text { Patholo- } \\
\text { gy }\end{array}$ & $\begin{array}{l}\text { Psychia- } \\
\text { try }\end{array}$ & $\begin{array}{l}\text { General } \\
\text { practice }\end{array}$ & $\begin{array}{l}\text { Public } \\
\text { health }\end{array}$ & $\begin{array}{l}\text { Other } \\
\text { medical }\end{array}$ & Total \\
\hline Medical specialties & 792 & 11 & 10 & 5 & 3 & 37 & 37 & 32 & 47 & 12 & 195 & 15 & 44 & 1240 \\
\hline Paediatrics & 13 & 270 & 6 & 1 & 1 & 8 & 5 & 12 & 15 & 8 & 84 & 11 & 8 & 442 \\
\hline $\begin{array}{l}\text { Accident and } \\
\text { emergency }\end{array}$ & 6 & 4 & 68 & 6 & - & 19 & 3 & - & 2 & 3 & 29 & - & 2 & 142 \\
\hline Surgery & 16 & 4 & 33 & 885 & 3 & 8 & 35 & 2 & 8 & 8 & 91 & 2 & 23 & 1118 \\
\hline $\begin{array}{l}\text { Obstetrics and } \\
\text { gynaecology }\end{array}$ & 4 & 2 & 2 & 4 & 203 & 1 & 3 & 7 & 1 & 3 & 47 & 8 & 1 & 286 \\
\hline Anaesthetics & 17 & 3 & 4 & 2 & 3 & 516 & 1 & 1 & - & 2 & 81 & 2 & 6 & 638 \\
\hline Radiology & 6 & 2 & - & - & - & 1 & 146 & 3 & 2 & 2 & 15 & 1 & - & 178 \\
\hline Clinical oncology & 14 & 2 & - & - & - & - & - & 68 & 5 & - & 9 & - & 3 & 101 \\
\hline Pathology & 17 & 1 & - & 2 & - & 1 & 6 & 7 & 274 & 4 & 20 & 10 & 4 & 346 \\
\hline Psychiatry & 7 & - & - & - & - & 2 & - & - & 2 & 377 & 26 & 5 & 8 & 427 \\
\hline General practice & 101 & 48 & 16 & 11 & 17 & 37 & 6 & 9 & 12 & 67 & 3054 & 74 & 39 & 3491 \\
\hline Public health & 4 & 11 & - & - & - & 1 & - & - & 1 & 7 & 10 & 31 & 3 & 68 \\
\hline Other medical* & 10 & 3 & 2 & 1 & 4 & 3 & 2 & - & 6 & 4 & 42 & 21 & 43 & 141 \\
\hline Total & 1007 & 361 & 141 & 917 & 234 & 634 & 244 & 141 & 375 & 497 & 3703 & 180 & 184 & 8618 \\
\hline
\end{tabular}

Emboldened numbers represent matches between career choice and destination.

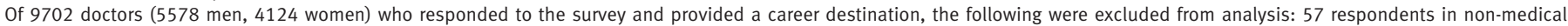

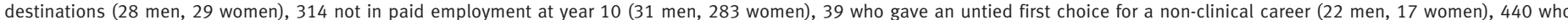
gave tied first choices ( 220 men, 220 women), and 234 who gave no career choice at year 3 (145 men, 89 women). 8618 doctors (5132 men, 3486 women) remained.

*See footnote to table 1 .

practice; in year 5 those who chose accident and emergency or anaesthetics were the most likely to change to general practice.

Transitions were analysed between the hospital specialties (excluding general practice and public health) by examining the sub-tables formed by the first 10 rows and columns of each of tables $4-6$. Some apparently large disparities exist between pairs of specialties (for example, more doctors choosing surgery and then doing anaesthetics than choosing anaesthetics and then doing surgery), which contribute to the overall appearance of asymmetry. However, the profile of changes between early choice and eventual destination will have been influenced by the availability of training and career posts in each specialty. Some specialties are larger than others and this influences the apparent asymmetry in some of the transitions between specialties. A quasi-symmetry model, which includes factors to adjust for the differences between total numbers in the marginal rows (choice) and marginal columns (destination), was fitted in each year and gave non-significant results (year 1: $\chi^{2}=47.0, \mathrm{df}=36, \mathrm{P}=0.10$; year 3 : $\chi^{2}=47.2, \quad \mathrm{df}=36, \mathrm{P}=0.10$; year $5: \chi^{2}=27.0, \mathrm{df}=36$, $\mathrm{P}=0.86$. In other words, after allowing for differences in numbers of posts in each specialty, evidence that transitions between hospital specialties followed any particular pattern was not statistically significant.

\section{DISCUSSION}

The eventual career destinations of doctors were more likely to match with the specialties chosen three years after graduation than one year after graduation, and match rates were higher still for choices made five years after graduation, by which time most doctors would nowadays have entered higher specialist training. The greater part of the increase occurred between years 1 and 3 , indicating that this is a key period in the definitive formation of young doctors' career plans.

Investigation of matches both ways-looking backwards as well as forwards - is important. For example, looking forward, general practice had the highest match of any specialty between year 1 choice and eventual destination; looking backwards, however, only half of the doctors whose eventual destination was in general practice had specified it as their first choice of career in year 1 . This shows that many doctors who want to be general practitioners from the outset achieve their ambition, but also that many doctors who initially aspire to other careers eventually work in general practice. As another example, less than two thirds of doctors who aspired to surgery in year 1 were surgeons in year 10; however, nine out of 10 doctors who were surgeons at year 10 had specified surgery as their first choice in year 1 . This shows that eventual success in surgery is only likely if surgery was always the intended specialty, but also that many with that early aspiration do not achieve it.

For many doctors choices had firmed up by the end of year 3. For example, only a third of doctors who aspired to radiology in year 1 became radiologists, whereas three quarters of those who aspired to radiology in year 3 eventually became radiologists.

In the period covered by these studies important changes occurred several times to postgraduate training. Each generation of doctors makes choices in the contemporaneous system; and it might be expected 
Table 6 | Untied first choice of specialty five years after graduation and career destination 10 years after graduation for doctors who qualified in 1974,1977 , 1993, and 1996

\begin{tabular}{|c|c|c|c|c|c|c|c|c|c|c|c|c|c|c|}
\hline \multirow[b]{2}{*}{ Year 5 choice } & \multicolumn{14}{|c|}{ Specialty Destination year 10} \\
\hline & $\begin{array}{l}\text { Medical } \\
\text { special- } \\
\text { ties }\end{array}$ & $\begin{array}{l}\text { Paedia- } \\
\text { trics }\end{array}$ & $\begin{array}{l}\text { Accident } \\
\text { and } \\
\text { emer- } \\
\text { gency }\end{array}$ & Surgery & $\begin{array}{l}\text { Obste- } \\
\text { trics and } \\
\text { gynae- } \\
\text { cology }\end{array}$ & $\begin{array}{l}\text { Anaes- } \\
\text { thetics }\end{array}$ & $\begin{array}{c}\text { Radiolo- } \\
\text { gy }\end{array}$ & $\begin{array}{l}\text { Clinical } \\
\text { oncology }\end{array}$ & $\begin{array}{c}\text { Patholo- } \\
\text { gy }\end{array}$ & $\begin{array}{c}\text { Psychia- } \\
\text { try }\end{array}$ & $\begin{array}{l}\text { General } \\
\text { practice }\end{array}$ & $\begin{array}{l}\text { Public } \\
\text { health }\end{array}$ & $\begin{array}{c}\text { Other } \\
\text { medical }\end{array}$ & Total \\
\hline $\begin{array}{l}\text { Medical } \\
\text { specialties }\end{array}$ & 776 & 8 & 4 & 4 & 1 & 7 & 4 & 8 & 13 & 4 & 71 & 9 & 19 & 928 \\
\hline Paediatrics & 7 & 234 & 3 & 1 & - & 3 & 3 & 6 & 7 & 4 & 30 & 7 & 4 & 309 \\
\hline $\begin{array}{l}\text { Accident and } \\
\text { emergency }\end{array}$ & 3 & 2 & 90 & 1 & 1 & 4 & - & - & - & 1 & 21 & 1 & - & 124 \\
\hline Surgery & 6 & 3 & 14 & 759 & 1 & 5 & 12 & - & 3 & 2 & 32 & - & 12 & 849 \\
\hline $\begin{array}{l}\text { Obstetrics and } \\
\text { gynaecology }\end{array}$ & 1 & - & - & - & 152 & 1 & 2 & 5 & 1 & 1 & 18 & 5 & 1 & 187 \\
\hline Anaesthetics & 5 & 4 & 1 & 1 & - & 465 & - & - & 1 & 2 & 31 & 3 & 5 & 518 \\
\hline Radiology & 3 & 1 & - & 1 & - & 1 & 190 & 3 & 5 & 1 & 3 & - & - & 208 \\
\hline Clinical oncology & 3 & 1 & 2 & - & 3 & - & 1 & 105 & 1 & 1 & 5 & - & 2 & 124 \\
\hline Pathology & 3 & - & - & - & - & 1 & - & 1 & 219 & 1 & 6 & 3 & 3 & 237 \\
\hline Psychiatry & 4 & - & 1 & - & - & 1 & - & - & 1 & 325 & 11 & 4 & 3 & 350 \\
\hline General practice & 50 & 19 & 4 & 3 & 6 & 11 & 3 & 4 & 4 & 15 & 2499 & 31 & 28 & 2677 \\
\hline Public health & 2 & 13 & - & - & 2 & - & - & - & 2 & 2 & 8 & 41 & 5 & 75 \\
\hline Other medical* & 6 & 4 & - & 3 & 4 & 3 & - & - & 8 & 6 & 27 & 24 & 37 & 122 \\
\hline Total & 869 & 289 & 119 & 773 & 170 & 502 & 215 & 132 & 265 & 365 & 2762 & 128 & 119 & 6708 \\
\hline
\end{tabular}

Emboldened numbers represent matches between career choice and destination.

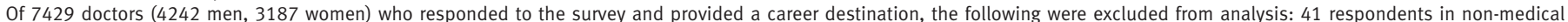

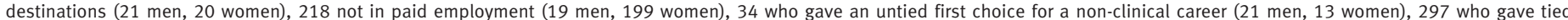
first choices (115 men, 182 women), and 131 who gave no career choice at year 5 ( 75 men, 56 women). 6708 doctors (3991 men, 2717 women) remained.

*See footnote to table 1 .

that patterns of choice and career destinations would be different between earlier cohorts and those who qualified more recently. However, despite changes to the structure of specialty training over time, matches between early choices and eventual destinations did not differ greatly. In fact, the percentages of doctors whose choice and destination matched and whose choice of specialty was definite were similar between the earlier and recent cohorts (tables 1-3). Our findings also indicate that, in any UK generation studied so far, appreciable percentages of doctors either have to change career direction or take advantage of opportunities to do so.

In the early cohorts, match rates between early choices and eventual destinations were significantly lower for women than for men. In the later cohorts the gap had diminished so that the difference was of marginal statistical significance only.

The tables provided can be used to study common and not so common combinations of changes between specialties. A substantial movement took place, as expected, from earlier choices for hospital specialties to general practice. Considering transitions between the hospital specialties, there was no statistical evidence that these changes followed a systematic pattern other than being associated with the relative size of specialties and therefore with the possible availability of posts.

\section{Strengths and weaknesses of the study}

The strengths of our study include its large size, the inclusion of all UK medical schools, the fact that it covers several cohorts of different generations, the high response rate, and the long period of follow-up. A crucial strength is that the study is prospective and longitudinal- that is, the doctors' choices of specialty in the early years were captured at that time. Recall biases, flawed recollections, and any tendency to rationalise early choices with hindsight are impossible. The study is also unique in that there is no other source of prospective data in the United Kingdom, collected from the doctors themselves, covering this period on the scale of ours.

The data in this paper are subject to the intrinsic limitation that data on matches between early choice and career destinations after 10 years are, by definition, limited to doctors who graduated at least a decade ago. It is too soon to tell whether recent cohorts, notably those who have sought posts in the era of Modernising Medical Careers, and those who entered medical school after the substantial expansion of medical school intake from 1999, will show different patterns of destination in relation to early choice.

As in any longitudinal study, a potential weakness is non-responder bias. The response rate was high for this kind of repeated survey design, but none the less it is possible that non-responders were less satisfied or perhaps more satisfied than responders with the relation between their earlier aspirations and later achievement.

\section{Comparisons with other studies}

Other large studies on early career choice and later destinations are sparse. One study used a series of cross sectional datasets to assess career progression. ${ }^{7}$ A literature review of studies of factors associated 


\section{WHAT IS ALREADY KNOWN ON THIS TOPIC}

Some UK medical graduates choose a specialty as soon as they qualify and others after a few years of postgraduate work

Changes to postgraduate medical training mean that junior doctors will generally have to make choices sooner than in the past

The timing of entry to training in different specialties is still under review

\section{WHAT THIS STUDY ADDS}

Ten years after graduating almost half of doctors worked in a specialty different from the one chosen in their first postgraduate year and about a quarter in a specialty different from their year 3 choice

Differences between specialties were considerable-for example, $90 \%$ of surgeons but only $50 \%$ of general practitioners had chosen their specialty in year 1

In some specialties, such as general practice and psychiatry, early choice was highly predictive of career destination; however, both specialties also attracted substantial numbers of doctors who had not initially chosen them

with choice of specialty commented that follow-up studies are few. ${ }^{8}$

Postgraduate training systems in some other countries, such as Australia, share similarities with those in the United Kingdom, including a few years of generalist training, whereas others, such as the United States, expect doctors to enter specialist training as soon as they graduate. Nevertheless, the issue of career intentions and the degree to which they accurately anticipate later career outcomes should be of interest to medical educators and doctors themselves, in any country. However, little evidence exists in the literature of systematic studies of early choice compared with eventual destinations outside the United Kingdom, although there are some projects that analyse the matching of applicants with training positions. For example, in the United States the national resident matching programme ${ }^{9}$ collates information on applications for, and appointments to, residency programmes.

\section{Interpretation and implications of the study}

Many doctors successfully pursued the specialty chosen in their first postgraduate year. It is also clear that many doctors had changed from their early choice of specialty. Early choices may not translate into eventual career pathways for several reasons, ${ }^{10}$ such as change of mind, lack of opportunity, and lack of success in achieving original aims. The supply of posts is one obvious determinant of the ease or otherwise of achieving a career in a chosen specialty. Compared with the availability of posts, too many newly qualified doctors in the United Kingdom want careers in hospital specialties and too few in general practice. An important element of medical training is to manage the expectations of medical students and young doctors about career opportunities in different specialties.

During the era covered by our study junior doctors had the opportunity, before committing to full specialty training, to sample different specialties and locations for longer than is typically the case now. It was also possible for them to try several entry points to specialty training by applying for junior jobs in the specialty at different times and in different locations. Some doctors will have changed specialty because the opportunity to change was there to try out; others will have changed because they really needed a different career direction. Specialty training in the United Kingdom now has a much more clearly defined starting point (and end point), with greater centralisation of application schemes.

Some of our respondents commented about an increasing lack of flexibility, as they saw it, in applying for specialty training. Some expressed concerns about having only one lifetime opportunity to succeed in getting on to a training programme for their chosen specialty. We suggest that at least two possible entry points should be available for most specialties - the first after one or perhaps two years of foundation training and the other at (say) three years. For some specialties, fast track training from the end of the first postgraduate year would seem appropriate. Many doctors intending to enter, for example, general practice, surgery, or psychiatry are wholly clear about their choice from the first year after graduation. For others, an additional opportunity for later entry to specialties such as general practice, psychiatry, or public health, which in the past have typically picked up "late transfers," seems appropriate. For some specialties, postgraduate experience before final commitment is important because exposure to the specialty in medical school is necessarily limited.

\section{Unanswered questions and future research}

For conciseness of presentation of match rates by specialty, we focused mainly on untied first choices rather than second or third preferences or tied first preferences. Our data show that second and third preferences and tied first preferences are much less predictive of eventual career destinations than are untied first choices. Within the datasets there is scope for further investigation of second and third preferences and combinations of specialty preference and career destinations.

This paper is based on analysis of specialty choice and career destination but does not explore the motivation behind any changes. Some changes are made for positive reasons, such as preferring the newly chosen specialty; others are made for negative reasons, such as disillusion with the specialty originally chosen or failure to get a training post. ${ }^{112}$ We have undertaken qualitative work on factors that influence choice of specialty and changes of choice, ${ }^{11}$ but consideration of these factors is beyond the scope of the present paper. Future work by others could complement our findings by seeking in-depth qualitative information from doctors who have changed career direction. It is also important to know whether recent changes to the structure of postgraduate training, with a requirement for doctors to choose specialties early, accompanied by what may be seen as reduced flexibility, really do create difficulties for an appreciable proportion of doctors. 
We thank the doctors who replied to our questionnaires and Janet Justice, Alison Stockford, and Emma Ayres for clerical assistance with the surveys and with data preparation.

Contributors: MJG and TWL designed the study. LL analysed the data. MJG and $L L$ wrote the first draft. All the authors contributed to further drafts, and all are guarantors. All authors had full access to all of the data in the study and take responsibility for the integrity of the data and accuracy of the data analysis.

Funding: The UK Medical Careers Research Group is funded by the Department of Health's policy research programme. The Unit of HealthCare Epidemiology is funded by the National Institute for Health Research. The study sponsors had no role in the design, conduct, analysis, or reporting of the study. The views and opinions expressed in this paper do not necessarily reflect those of the sponsors.

Competing interests: All authors have completed the Unified Competing Interest form at www.icmje.org/coi_disclosure.pdf (available on request from the corresponding author) and all authors want to declare: (1) financial support for the submitted work from the policy research programme, Department of Health. All authors also declare: (2) no financial relationships with commercial entities that might have an interest in the submitted work; (3) no spouses, partners, or children with relationships with commercial entities that might have an interest in the submitted work; (4) no non-financial interests that may be relevant to the submitted work.

Ethical approval: This study was approved by the Central Office for Research Ethics Committees, after referral to Brighton, Mid Sussex, and East Sussex local research ethics committees.

Data sharing: No additional data available.

1 Working Group on Specialist Medical Training. Hospital doctors: training for the future. Department of Health, 1993.
2 Calman KC, Temple JG, Naysmith R, Cairncross RG, Bennett SJ. Reforming higher specialist training in the United Kingdom-a step along the continuum of medical education. Med Educ 1999;33:28-33.

3 Donaldson L. Unfinished business: proposals for reform of the senior house officer grade. NHS Executive, 2002.

4 Tooke J. Aspiring to excellence: findings and final recommendations of the Independent Inquiry into Modernising Medical Careers. M MC Inquiry, 2007.

5 Lambert TW, Goldacre MJ, Edwards C, Parkhouse J. Career preferences of doctors who qualified in the United Kingdom in 1993 compared with those of doctors qualifying in 1974, 1977, 1980, and 1983. BMJ 1996;313:19-24.

6 Agresti A. Categorical data analysis. Wiley, 1990.

7 McManus IC, Sproston KA. Women in hospital medicine in the United Kingdom: glass ceiling, preference, prejudice or cohort effect? J Epidemiol Community Health 2000;54:10-6.

8 Soethout MBM, ten Cate Th J, van der Wal G. Factors associated with the nature, timing and stability of the specialty career choices of recently graduated doctors in European countries, a literature review. 2004. www.med-ed-online.net/index.php/meo/article/view/4360/ 0.

9 National Resident Matching Program. Results and data: 2009 main residency match. 2009. www.nrmp.org/data/resultsanddata2009.pdf.

10 Taylor KS, Lambert TW, Goldacre MJ. Career progression and destinations, comparing men and women in the NHS: postal questionnaire surveys. BMJ 2009;338:b1735.

11 Lambert TW, Davidson JM, Evans J, Goldacre MJ. Doctors' reasons for rejecting initial choices of specialties as long-term careers. Med Educ 2003;37:312-8.

12 Lambert TW, Turner G, Fazel S, Goldacre MJ. Reasons why some UK medical graduates who initially choose psychiatry do not pursue it as a long-term career. Psychol Med 2006:36:679-84.

Accepted: 3 June 2010 